\title{
Histopathological Spectrum of Basal Cell Carcinoma-7 Years Retrospective Study
}

\author{
Somil Singhal* \\ Consultant Pathologist, Kriti Pathology (A Complete Diagnostic Solution), A Unit of Kriti Scanning Centre (P) Ltd., \\ Allahabad, India
}

*Address for Correspondence: Dr. Somil Singhal, Consultant Pathologist, Kriti Pathology (A Complete Diagnostic Solution), A Unit of Kriti Scanning Centre (P) Ltd. Allahabad, Uttar Pradesh, India

E-mail: somil15feb@gmail.com

Received: 21 Sep 2019/ Revised: 26 Dec 2019/ Accepted: 23 Feb 2020

\begin{abstract}
Background: Basal cell carcinoma is the most common malignant tumour of the skin worldwide. The objective was to find out the age and sex incidence of basal cell carcinoma in patients attending the outpatient department of dermatology and to find out the various clinical and histopathological features of basal cell carcinoma.

Methods: It was a retrospective study carried out in a NABH, NABL and JCl accredited hospital, New Delhi, India. Patients with a clinical diagnosis of basal cell carcinoma were included in the study after thorough history, clinical examination, routine and special investigations like skin biopsy.

Results: Out of 20 patients with basal cell carcinoma 6 were males and 14 were females with a male to female ratio of 1:2.33. Most commonly affected age group was $51-70$ years (70\%). Distribution of BCC in our study was confined to head and neck area. Most common morphological subtype encountered in this study was nodular/nodulo-ulcerative BCC (70\%), followed by the pigmented type (25\%) and superficial BCC (5\%). The most common histological variant observed in the present study i.e. nodular type $(55 \%)$, followed by the pigmented variant $(25 \%)$, adenoid $(5 \%)$, basosquamous $(5 \%)$, superficial BCC (5\%) and BCC with sebaceous differentiation (5\%).

Conclusion: This study highlights a paradoxically increasing trend of BCC with female predilection. Early detection and treatment of lesions are crucial to decrease the functional and cosmetic disfigurement and also this study highlights the importance of improving awareness among general practitioners, public health workers and the general population.
\end{abstract}

Key-words: Basal cell carcinoma, Clinical variants, Excision biopsy, Histopathology

\section{INTRODUCTION}

Basal cell carcinoma is the most common malignant skin tumor and the most prevalent cancer type among whiteskinned populations worldwide and particularly in industrialized Western societies [1]. In addition, the incidence of skin cancer is rising all over the world. Geographical location plays an extremely important role in the distribution and frequency of incidence rates. In people with outdoor occupations like miners, quarry men, railway engine drivers and firemen, the frequency of BCC is high ${ }^{[2]}$.

\section{How to cite this article}

Singhal S. Histopathological Spectrum of Basal Cell Carcinoma-7 Years Retrospective Study. SSR Inst. Int. J. Life Sci., 2020; 6(2): 2487-2493.

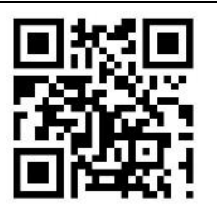

Access this article online https://iijls.com/
It is a slow-growing malignant tumour of the skin that invades the adjacent tissues with a metastatic incidence of $0.01 \%-0.028 \%$. ${ }^{[3]}$ Ultraviolet radiation plays a major role in the development of BCCs. Radiation exposure, exposure to arsenic salts, chemical carcinogens, chronic irradiation, chronic inflammation, pre-existing skin lesions such as discoid lupus erythematosus, burn scar and vaccination scar are the various other causal factors ${ }^{[4]}$. Ethnical differences in types of skin, immunological and genetic factors also play a role in the development of BCC. Males are more commonly affected than females. BCC generally occurs in adults over 40 years of age, but it may occur in children and young adults ${ }^{[5]}$. In children, it is usually associated with genetic defects such as xeroderma pigmentosum, nevus sebaceous, nevoid basal cell syndrome, Rombo syndrome or Bazex syndrome, Brooke-Spiegler syndrome. 


\section{MATERIALS AND METHODS}

It was a retrospective study conducted for a period of seven years from September 2004 to September 2011 in patients attending outpatient Department of Dermatology, Maharaja Agrasen Hospital, New Delhi, India.

The patients, who attend the dermatology outpatient department, with a clinical diagnosis of basal cell carcinoma were selected for the study. Thorough history related to age, sex, occupation and the duration of the lesions was noted. Specific and relevant history about the lesion was taken, including family history. History of any medical or surgical interventions also noted. Thorough clinical examination of the lesions with reference to site, number, size, shape, colour, surface border and consistency of the lesion were also noted. Routine investigations like complete blood count, random blood sugar, bleeding time, clotting time, HIV 1 and 2 antibody, VDRL and X- ray chest was taken from all the patients. Using pretested proforma, patient details, clinical findings and investigations were recorded. Excision biopsy was done in the dermatology operating room. Excised specimen was received for histopathological examination. Sections were stained with $\mathrm{H}$ and $\mathrm{E}$ and studied in both low and high-power magnifications. Pathologist opinion was obtained. The clinical and histopathological correlation were done.

Inclusion criteria- Patient, who was ready to give consent for pictures and biopsy procedure for study.

Exclusion Criteria- Patients with known congenital abnormalities, HIV patients/ known malignancy or chemotherapy/ pregnant patients and those, who were not willing to give consent for biopsy procedure.

Ethics approval and consent to participate- The above study was approved by the Human Ethical Committee (Ethics Committee approval number: SNMC/IECHSR/ 20141/A-14c1.1 dated 19 November 2014) of the "S Nijalingappa Medical College, HSK (Hanagal Shree Kumareshwar) Hospital and Research Centre, Nava Nagar, Bagalkot, Karnataka and informed consent was obtained from the patients before the study.

\section{RESULTS}

A total of 20 patients with basal cell carcinoma were included in the study. Out of these, 6 patients were males and 14 patients were females. Hence, in our study basal cell carcinoma was more common in females (70\%) than males (30\%). Male to female distribution was 1 : 2.33 .

Age distribution of Basal cell carcinoma- Age of the patients ranged from $10-80$ years. The most commonly affected age group was 51-60 years with 8 (40\%) patients, closely followed by 61-70 years age group with 6 (30\%) patients. Hence, in our study basal cell carcinoma was more common in the age group of 51-60 years are given in Table 1.

Table 1: Age wise age distribution of Basal Cell Carcinoma

\begin{tabular}{ccccc}
\hline $\begin{array}{c}\text { Age } \\
\text { groups }\end{array}$ & Males & Females & Total & $\begin{array}{c}\text { Percentage } \\
\mathbf{( \% )}\end{array}$ \\
\hline $11-20$ & 1 & 0 & 1 & 5 \\
$21-30$ & 0 & 0 & 0 & 0 \\
$31-40$ & 2 & 0 & 2 & 10 \\
$41-50$ & 1 & 0 & 1 & 5 \\
$51-60$ & 2 & 6 & 8 & 40 \\
$61-70$ & 0 & 6 & 6 & 30 \\
$71-80$ & 0 & 2 & 2 & 10 \\
\hline
\end{tabular}

Distributions of Basal cell carcinoma according to siteDistribution of lesions were confined to head and neck area. The most common site of involvement was nose (30\%). It was followed by periocular area (25\%), cheek $(15 \%)$, forehead $(10 \%)$, post auricular area $(10 \%)$, upper lip (5\%) and chin (5\%) are given in Table 2.

Table 2: Site wise distribution of Basal Cell Carcinoma

\begin{tabular}{cc}
\hline Site & Numbers of cases (\%) \\
\hline Nose & $6(30 \%)$ \\
Periocular area & $5(25 \%)$ \\
Cheek & $3(15 \%)$ \\
Forehead & $2(10 \%)$ \\
Post auricular area & $2(10 \%)$ \\
Upper lip & $1(5 \%)$ \\
Chin & $1(5 \%)$ \\
\hline
\end{tabular}


Morphological types of Basal cell carcinoma- Most common morphological subtype of basal cell carcinoma was nodular /nodulo-ulcerative growth (70\%). It was followed by pigmented variant (25\%) and superficial basal cell carcinoma (5\%) is given in Table 3.

Table 3: Morphological types of basal cell carcinoma

\begin{tabular}{ccc}
\hline Morphology & $\begin{array}{c}\text { Number of } \\
\text { Cases }(\mathbf{n = 2 0})\end{array}$ & $\begin{array}{c}\text { Percentage } \\
\mathbf{( \% )}\end{array}$ \\
\hline $\begin{array}{c}\text { Nodular / Nodulo- } \\
\text { ulcerative }\end{array}$ & 14 & 70 \\
Pigmented & 5 & 25 \\
Superficial & 1 & 5 \\
\hline
\end{tabular}

The gross variant of nodulo-ulcerative growth, pigmented variant of nodular basal cell carcinoma, and nodular variant suggestive of xeroderma pigmentosum are described in Fig. 1, 2 \& 3.

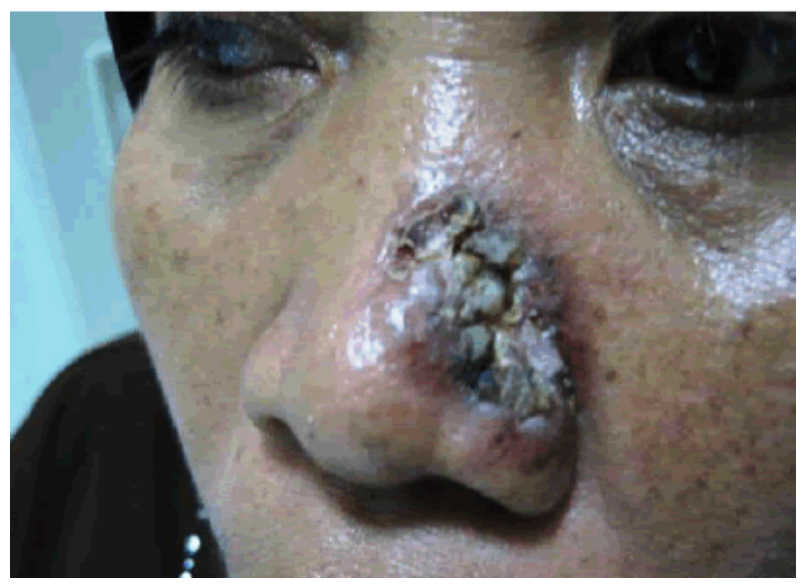

Fig. 1: Gross variant of nodulo-ulcerative growth (Nodulo-ulcerative growth on left cheek, Demarcated, irregular blackish brown color, erythmatous edge)

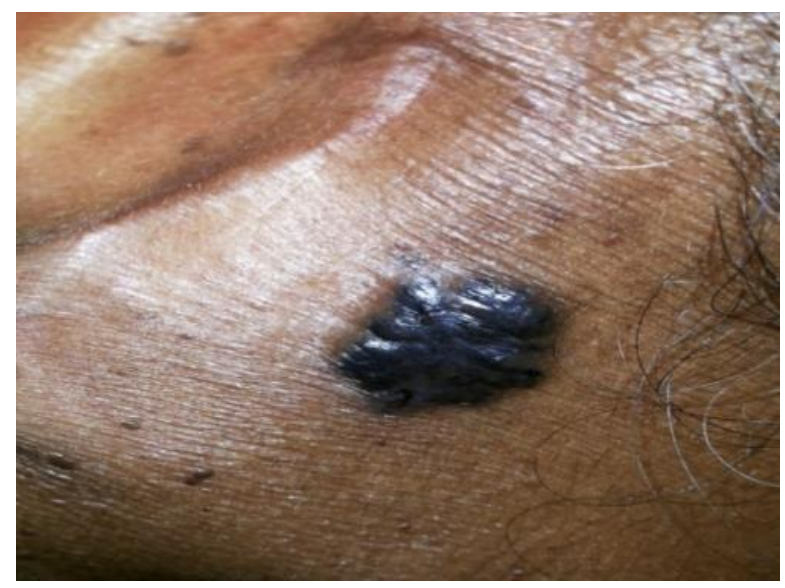

Fig. 2: Gross variant of Nodular basal cell carcinoma, pigmented variant

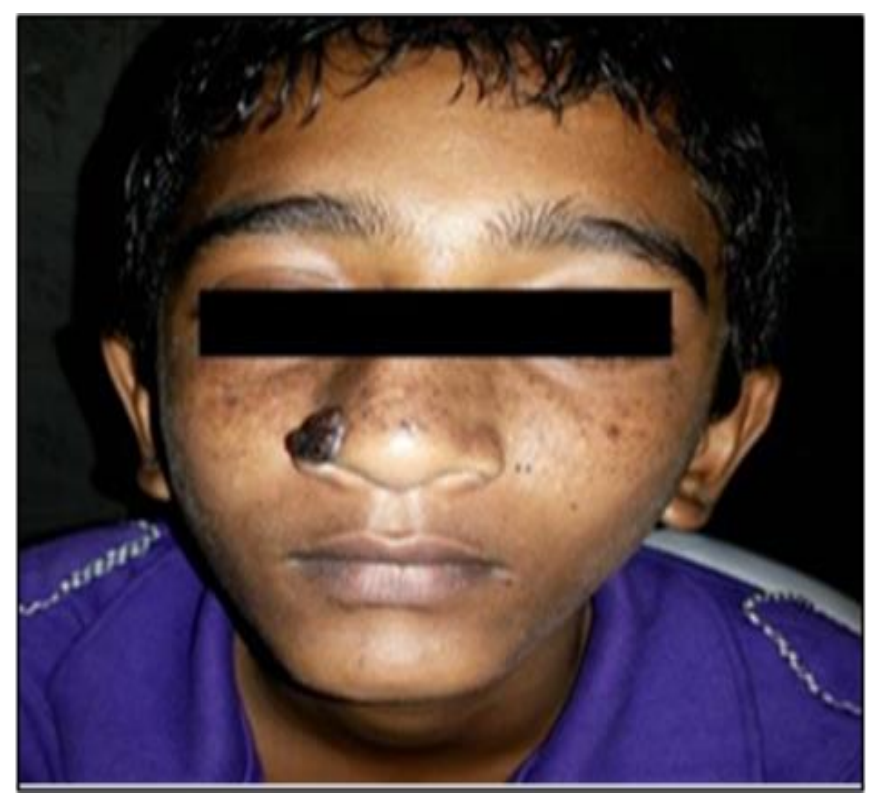

Fig. 3: Gross Variant of Nodular Basal Cell Carcinoma (Diffuse freckling on face suggestive of Xeroderma pigmentosum and Nodulo-ulcerative growth on right side of nose)

Histopathological variants of BCC- The various microscopic subtypes of basal cell carcinoma were shown in Fig. 4, 5, 6 \& 7. The most common histopathological variant was nodular subtype (55\%) with significant proportion of tumors being pigmented (25\%). Other subtypes included basosquamous (5\%), adenoid variant (5\%), BCC with sebaceous differentiation (5\%) and superficial BCC (5\%).

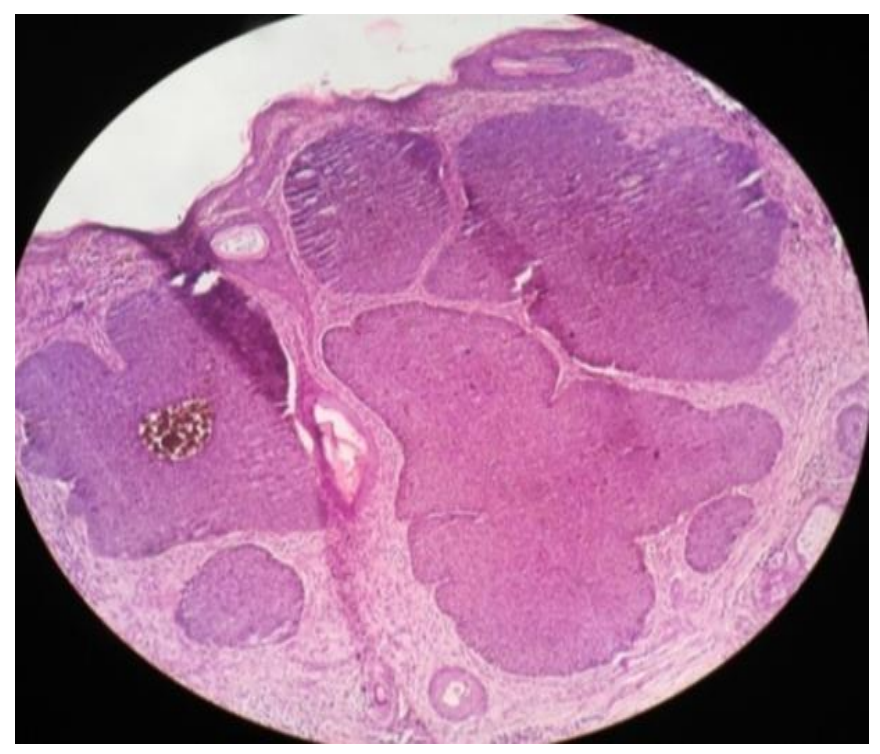

Fig. 4: Nodular basal cell carcinoma shows nodular tumour with peripheral palisading 


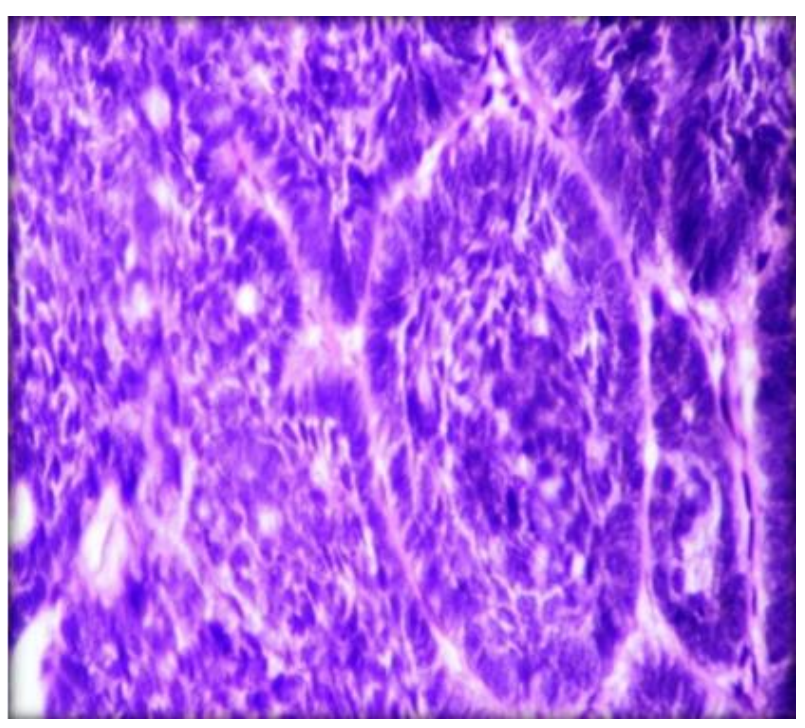

Fig. 5: Nodular basal cell carcinoma shows nodular tumour with peripheral palisading by having retraction artifact

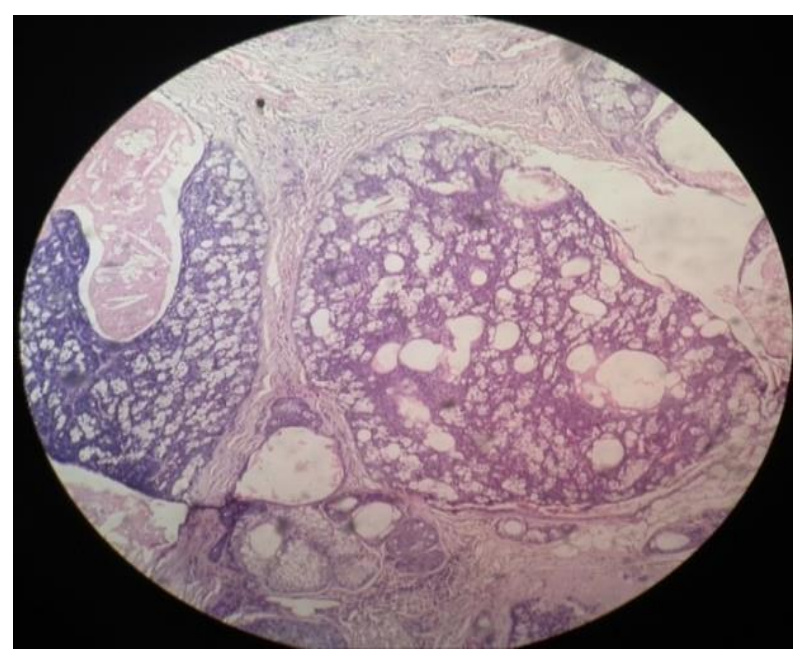

Fig. 6: $\mathrm{BCC}$ with sebaceous differentiation

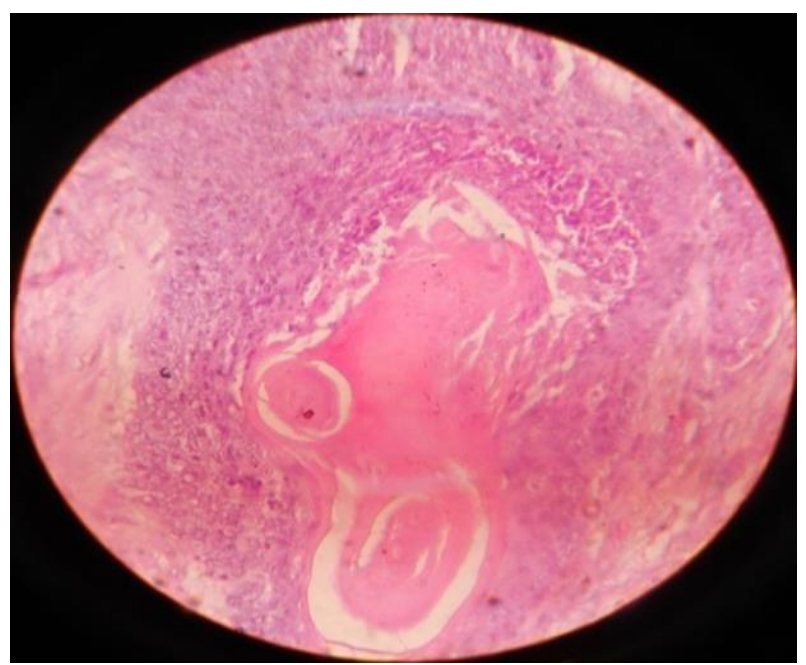

Fig. 7: Baso squamous carcinoma showing focal keratinization
Various immunohistochemical markers were used to differentiate from adnexal neoplasms and to rule out the mimics of basal cell carcinoma are included in Table 4, 5, $\& 6$.

Table 7 includes the immunohistochemistry studies to confirm the diagnosis of basal cell carcinoma.

Table 4: IHC study to rule out the mimics of superficial variant of basal cell carcinoma

\begin{tabular}{|c|c|c|c|}
\hline $\begin{array}{c}\text { Differential } \\
\text { Diagnosis }\end{array}$ & $\begin{array}{c}\text { IHC } \\
\text { Marker }\end{array}$ & Positive & Negative \\
\hline Trichoepithelioma & CD 10 & $\begin{array}{c}\text { + Peritumoral, } \\
\text { Stromal } \\
\text { reaction }\end{array}$ & - \\
\hline Sebaceoma & $\begin{array}{l}\text { BerEp4 } \\
\text { EMA }\end{array}$ & $\begin{array}{c}\text { Rarely + } \\
\text { Typically + }\end{array}$ & - \\
\hline $\begin{array}{l}\text { Microcystic } \\
\text { adnexal } \\
\text { carcinoma }\end{array}$ & CK 20 & - & - \\
\hline $\begin{array}{l}\text { Basal Cell } \\
\text { Carcinoma }\end{array}$ & $\begin{array}{l}\text { BCL-2, } \\
\text { Ber-Ep4 } \\
\text { CD34 }\end{array}$ & - & - \\
\hline
\end{tabular}

Table 5: Immunohistochemistry study to rule out the mimics of Morphoeic variant of basal cell carcinoma

\begin{tabular}{ccc}
\hline $\begin{array}{c}\text { IHC } \\
\text { Markers }\end{array}$ & $\begin{array}{c}\text { Basal Cell } \\
\text { Carcinoma }\end{array}$ & Trichoblastoma \\
\hline CD 10 & $\begin{array}{c}\text { Present in } \\
\text { Epithelium }\end{array}$ & $\begin{array}{c}\text { Present in } \\
\text { Peritumoral }\end{array}$ \\
BCL2 & Absent & Absent \\
\hline
\end{tabular}

Table 6: Immunohistochemistry studies to rule out the mimics of Baso squamous variant of basal cell carcinoma

\begin{tabular}{ccc}
\hline IHC Markers & $\begin{array}{c}\text { Basal Cell } \\
\text { Carcinoma }\end{array}$ & $\begin{array}{c}\text { Basosquamous } \\
\text { Variant }\end{array}$ \\
\hline 34 BETA E 12 & - & + \\
AE1/AE3 & - & + \\
MNF116 & - & + \\
CK 5/6 & + & + \\
CAM 5.2 & - & - \\
BerEP4 & - & - \\
S100P & - & - \\
\hline
\end{tabular}


Table 7: Immunohistochemistry studies to confirm the diagnosis of basal cell carcinoma

\begin{tabular}{ccc}
\hline IHC Markers & Positive & Negative \\
\hline CK 5 & + & - \\
CK 6 & + & - \\
CK 14 & + & - \\
CK 7 & + & - \\
Ber EP4 & + & - \\
& Nuclear & - \\
P63 & Expression & - \\
CK 20 & - & - \\
EMA & - & - \\
CEA & - & - \\
\hline
\end{tabular}

\section{DISCUSSION}

This study included a total of 20 patients with basal cell carcinoma. Among these 6 patients were males and 14 patients were females. In this study, females were more commonly affected (70\%) than males (30\%) with a male to female ratio of $1: 2.33$. It was consistent with Laishram et al. ${ }^{[6]}$ study 'pattern of skin malignancies in Manipur, India, which shown male to female ratio of $1: 2$ and contrast to western studies that conducted by Hakverdi et al. ${ }^{[7]}$, retrospective analysis of basal cell carcinoma showed male preponderance.

BCCs are more common in males as reported in most studies worldwide, presumably due to greater occupational exposure to ultraviolet radiation (UVR). However, an unusual female preponderance was noticed in our study ${ }^{[8]}$. Since Indian housewives, especially rural women work in open kitchen during their household chores and work in the fields during sowing and harvesting seasons exposing them to intermittent, high intensity UVR. It might explain the higher frequency of BCC in females in our study as intermittent rather than constant, cumulative UVR exposure was implicated in the pathogenesis of BCC. This female predilection may also be attributed to structurally thinner skin with lower collagen density in the dermis when compared to men ${ }^{[9]}$.

The most commonly affected age group in this study was
$51-60$ years $(40 \%)$, followed by $61-70$ years $(30 \%)$ with a mean age of 56.7 years. It was similar to a study conducted by Obaidullah and Aslam, which showed a mean age of 56.3 years ${ }^{[8]}$. Maximum age of the patient affected by BCC in our study was 72 years and the youngest age was 14 years. Although basal cell carcinoma is rare in younger individuals, an increased incidence has also been noticed in children and young adults ${ }^{[5]}$. Here, we reported a 14 year old male patient with diffuse freckling on the face suggestive of xeroderma pigmentosum and nodulo- ulcerative type of basal cell carcinoma on right side of nose. Xeroderma pigmentosum is a rare autosomal recessive disease characterized by photosensitivity, pigmentary changes and early neoplasia resulting from abnormal DNA repair. Higher rates of occurrence of $B C C$ among the elderly may be due to cumulative UVR induced DNA damage as well as reduced efficiency of immune-surveillance and DNA repair mechanisms with aging ${ }^{[9]}$.

The distribution of BCC in the present study was confined head and neck area. The most common site of involvement was nose $(30 \%)$, followed by periocular area $(25 \%)$ and cheek (15\%). It was similar to a study conducted by Malhotra et al. [10] 'Basal cell carcinoma in the north Indian population' which showed head and neck being the commonest site (91.2\%). Another study conducted by Asif et al. ${ }^{[11]}$, showed nose being the common site (28.9\%) followed by eye $(24.7 \%)$ and cheek (20.4\%), which was closely resembles to this study. The most common morphological sub type of BCC encountered in our study was nodular/nodulo-ulcerative type (70\%), followed by pigmented BCC (25\%) and superficial BCC (5\%).

These findings are consistent with a study conducted by Sumirkumar et al. ${ }^{[12]}$, 'A study of basal cell carcinoma in south Asians' which showed common morphological subtype is being nodular/nodulo-ulcerative BCC (77.8\%) and pigmented $\mathrm{BCC}(22.2 \%)$. The patients with nodular type of BCC, having cutaneous features of skin coloured or hyperpigmented papules, nodules and plaques were present on head and neck area most commonly on nose, periocular and cheek. Some patients with noduloulcerative lesions showed surface changes like ulceration and crusting ${ }^{[13]}$. The patients with pigmented BCC were present as nodular lesions with grey-black pigmentation ${ }^{[14]}$. In our study, 5 patients were appearing clinically pigmented. Superficial BCC usually 
appears as erythematous, scaly patches that slowly increase in size by peripheral extension with fine thread like border. The patches usually show superficial ulceration, crusting and sometimes with central atrophic scarring. Superficial BCC usually occurs on the trunk. But in our study, one female patient was present with superficial BCC on forehead. The most common histopathological variant in our study was nodular type (55\%) with a significant proportion of tumours being pigmented (25\%). Other subtypes included adenoid (5\%), basosquamous (5\%), superficial (5\%) and BCC with sebaceous differentiation (5\%).

These findings closely resembled Malhotra et al, study which shows the nodular type being the most common histologic variant (64.7\%) ${ }^{[10]}$. Common histological features of basal cell carcinomas are Basaloid tumor cells, Peripheral palisading of lesional cell nuclei and clefting artefact between the epithelium and stroma. It was the most common histological subtype observed in our study. $\mathrm{H}$ and $\mathrm{E}$ stained smears showed nodules of basaloid cells with peripheral palisade arrangement and peritumoral lacunae were noted in all cases. Some cases showed cystic spaces within tumour masses. It was the second most common histological subtype in our study. Histological features resembled with nodular BCC, in addition in the presence of melanin within tumour cells and macrophages were noted in pigmented variant.

One case presented with superficial BCC with typical features of buds and irregular proliferation of tumour tissue attached to the under surface of the epidermis. This was the rare histopathological variant of BCC. Here we observed one case with Adenoid basal cell carcinoma. In this type tumour cells were arranged within clusters and focal lace like pattern of cells were made out. It was a rare histological variant of BCC, which shows cystic spaces within the tumour lobules. Here one case presented clinically as nodular type of BCC and histology showed BCC with sebaceous differentiation ${ }^{[15]}$. In this study, we observed one rare case with histological findings suggestive of baso squamous carcinoma, which was clinically; appear as noduloulcerative form of BCC. Basosquamous carcinoma (BSC) is a rare epithelial neoplasm with histological features of both basal cell carcinoma (BCC) and squamous cell carcinoma (SCC) and it is linked by a transition zone. It is also known as metatypical epitheliomas. The most common location of BCC is on the head and neck and mainly involving the central face and has a significant male predominance ${ }^{[16]}$. In contrast to pure BCC, basaloid cells in basosquamous carcinoma have eosinophilic cytoplasm, often with lack of peripheral palisading and retraction artifact and may exhibit cytoplasmic keratinisation ${ }^{[17]}$. Like squamous cell carcinoma, basosquamous carcinoma also more aggressive and locally invasive ${ }^{[18,19]}$. The risk of metastasis is more in basosquamous carcinoma than forms of BCC. Metastatic basosquamous carcinoma is difficult to treat and its prognosis is poor ${ }^{[20-22]}$.

\section{CONCLUSIONS}

Most nodular basal-cell cancers can be diagnosed clinically; however, other variants can be very difficult to distinguish from benign lesions such as intradermal nevus, sebaceomas, fibrous papules, early acne scars, and hypertrophic scarring, so early detection on histopathological study of BCC is important to improve the cure rate. Histopathological study is one of the most valuable means of diagnosis in dermatopathology and the diagnosis of BCC can be done by correlating clinical features, gross and histological appearances. The present study emphasized the various patterns of BCC in this geographic location in and around the city.

The clinical and epidemiological data collected in this study would serve as a reference for future research and may be helpful in the development of preventive and educational strategies.

\section{CONTRIBUTION OF AUTHORS}

Dr. Somil Singhal is only contributed in this article.

\section{REFERENCES}

[1] Brewster DH, Bhatti LA, Inglish JHC, Nain ER, Doherty VR. Recent trends in incidence of nonmelanoma skin cancer in the East of Scotland, 1992-2003. Br. J. Dermatol., 2007; 156: 1295-300.

[2] Suarez B, Lopez-Abente G, Martinez C. Occupation and skin cancer: the results of the HELIOS-I multicenter case-control study. BMC Public Health. 2007; 7: 180.

[3] Swan PG, Weir J. Is it blephritis? Clin. Exp. Optom., 2005; 88: 113-14.

[4] Crowson AN. Basal cell carcinoma: Biology, morphology and clinical implications. Modern Pathol., 2006; 19: 127-47. 
[5] Christenson L, Borrowman TA, Vachon CM, Tollefson MM, Otley CC, et al. Incidence of basal cell and squamous cell carcinomas in a population younger than 40 years. JAMA, 2005; 294: 681-90.

[6] Laishram RS, Banerjee A, Punyabati P, Sharma LD. Pattern of skin malignancies in Manipur, India: A 5year histopathological review. J. Pak. Assoc. Dermatol., 2016; 20(3): 128-32.

[7] Hakverdi S, Balci DD, Dogramaci CA, Toprak S, Yaldiz M. Retrospective analysis of basal cell carcinoma. Indian J. Dermatol. Venereol. Leprol., 2011; 77: 251.

[8] Ullah O, Aslam M, Afridi N. Preliminary report on recurrence of Basal Cell Carcinoma (bcc) after surgical excision in NWFP and Afghanistan. J. Postgrad. Med. Inst., 2008; 22(4): 270-73.

[9] Gallagher RP, Hill GB, Bajdik CD, Fincham S, Coldman AJ, McLean DI, et al. Sunlight exposure, pigmentary factors, and risk of nonmelanocytic skin cancer: I. Basal cell carcinoma. Arch. Dermatol., 1995; 131(2): 157-63.

[10]Malhotra P, Singh A, Ramesh V. Basal cell carcinoma in the North Indian population: Clinicopathologic review and immunohistochemical analysis. Indian J. Dermatol. Venereol. Leprol., 2011; 77(3): 328.

[11]Asif M, Mamoon N, Ali Z, Akhtar F. Epidemiological and excision margin status of basal cell carcinomathree years armed forces institute of pathology experience in pakistan. Asian Pacific J. Cancer Prevent., 2010; 11(5): 1421-23.

[12]Kumar S, Mahajan BB, Kaur S, Yadav A, Singh N, Singh A. A study of Basal Cell Carcinoma in South Asians for risk factor and clinicopathological characterization: A hospital based study. J. Skin Cancer, 2014; 2014: 1-9.

[13]Puri T, Gunabushanam G, Sharma R, et al. Extensive bone metastases from basal cell carcinoma of the eye. Singapore Med. J., 2006; 47: 811-13.
[14]Zhang H, Yan J, Li Y Zhang P. Mucoepidermoid carcinoma of the eyelid: a case report and review of the literature. Eye Sci., 2005; 21(3): 152-57.

[15] Papalkar D, Sharma S, Francis IC, et al. Red eye and a rodent ulcer. Ophthal. Plast. Reconstr. Surg., 2006; 22: 131-32.

[16]Cockerell CJ, Tran KT, Caruuci J, et al. Basal cell carcinoma. In: Rigel DS, Robinson JK, Ross M, et al., eds. Cancer of the Skin, 2016.

[17]Charkravorthy RC and Choudhuri DR. Malignant neoplasms of the skin in Eastern India. Ind. J. Cancer, 1968: 5: 133-44.

[18]Goldenberg G, Hamid O. Nonsurgical treatment options for basal cell carcinoma - focus on advanced disease. J. Drugs Dermatol., 2013; 12(12): 1369-78.

[19] Quirk C, Gebauer K, De'Ambrosis B, et al. Sustained clearance of superficial basal cell carcinomas treated with imiquimod cream $5 \%$ : results of a prospective 5-year study. Cutis., 2010; 85(6): 318-24.

[20] Prokosch V, Thanos S, Spaniol K, Stupp T. Long-term outcome after treatment with $5 \%$ topical imiquimod cream in patients with basal cell carcinoma of the eyelids. Graefes. Arch. Clin. Exp. Opthalmol., 2011; 249(1): 121-25.

[21]. Van der geer S, Martens J, Van roij J, et al. Imiquimod 5\% cream as pretreatment of Mohs micrographic surgery for nodular basal cell carcinoma in the face: a prospective randomized controlled study. Br. J. Dermatol., 2012; 167(1): 110-15.

[22]Bath-Hextall F, Ozolins M, Armstrong SJ, et al. Surgical excision versus imiquimod $5 \%$ cream for nodular and superficial basal-cell carcinoma (SINS): A multicentre, non-inferiority, randomised controlled trial. Lancet Oncol., 2014; 15(1): 96-105.

\section{Open Access Policy:}

Authors/Contributors are responsible for originality, contents, correct references, and ethical issues. SSR-IIJLS publishes all articles under Creative Commons Attribution- Non-Commercial 4.0 International License (CC BY-NC). https://creativecommons.org/licenses/by-nc/4.0/legalcode (c) (1) (9) 